\title{
Thermometric Bridge Circuits for Measuring Thermophysical Properties
}

\author{
Ihor Vasylkivskyi*, Vasyl Fedynets, Yaroslav Yusyk \\ Lviv Polytechnic National University, 12 Stepana Bandery St., Lviv, 79013, Ukraine
}

Received: October 14, 2020. Revised: November 06, 2020. Accepted: November 13, 2020.

(C) 2020 The Authors. Published by Lviv Polytechnic National University.

\begin{abstract}
The article presents the designs of a number of devices for measuring the thermal conductivity of solids developed using the new methodological approaches proposed by the authors, which enable measurements in a wide range of thermal conductivity values with better accuracy. The proposed approaches rely on the principle of invariance, which consists in ensuring the compensation of the effect of various non-informative parameters on the measurement result. For calculating the developed thermometric bridge circuits (balanced, unbalanced and partially balanced), there was applied the theory of thermal circuits based on the similarity between heat transfer and electricity transfer. The design of thermometric devices based on thermometric bridge circuits makes it possible to raise significantly the accuracy of measuring thermophysical properties of materials due to the reduced errors stemming from the effect of non-informative parameters on the measurement result. This, in turn, allowed the extended measurement range for the thermal conductivity, increased reliability and reduced cost of the devices owing to the simplified measuring circuit.
\end{abstract}

Keywords: thermal conductivity coefficient; thermometric bridge circuit; test specimen; reference specimen; thermal resistance; thermal conductivity circuit.

\section{Statement of the research problem}

Many research and technology areas now need thermophysical measurements. Reliable data on thermophysical properties of materials are essential for a number of priority areas. These are associated with energy saving in constructing various-use objects, energy consumption cutting in heat generation, transfer and saving, and reducing environmental pollution caused by generation of heat for domestic and industrial purposes, space industry development, designing radio-electronic devices (rejection of heat from powerful radiating and radio elements), development of new modern materials, etc.

Thermal modes of various devices used in the above-listed areas of research and technology are strictly regulated and calculated based on the experimental data on thermophysical properties both for construction materials and for working substances. Regretfully, the low effectiveness and considerable complexity of the methods and tools used nowadays significantly complicate such studies.

Full-scale production of thermal conductivity devices has not been launched in Ukraine, although the solutions have been developed by the Department of Thermal Measurements of the Institute of Engineering Thermophysics (NAS of Ukraine) and other research institutions [1], [2]. However, the proposed devices have some drawbacks. They are geared to study thermophysical properties of specifically sized specimen, are mostly used for measurements within a narrow range of thermal conductivity values, etc. Therefore, the array of topical research problems to be solved in the area of thermophysical measurements includes the development of new methodological approaches that

\footnotetext{
* Corresponding author. Email address: ihor.s.vasylkivskyi@lpnu.ua
}

This paper should be cited as: I. Vasylkivskyi, V. Fedynets, Y. Yusyk. Thermometric bridge circuits for measuring thermophysical properties. Energy Engineering and Control Systems, 2020, Vol. 6, No. 2, pp. 127 - 136. https://doi.org/10.23939/jeecs2020.02.127 
will make it possible to make high-accuracy measurements across a wide range of thermal conductivity values, and, as a result, of new thermophysical devices, more advanced as compared to the existing ones.

\section{Analysis of the recent publications and studies}

In the known solutions for thermophysical devices, the measurement accuracy was enhanced by improving the measurement techniques, manufacturing technologies and design of the existing devices [2], [3]. Thereat, their insensitivity to non-informative parameters was achieved by the design and engineering methods of parametric stabilization that are implementable using assemblies and higher quality elements with better stability (guarding heaters, an intricate system of heat shields, top-accuracy thermal couple with reduced-diameter electrodes, etc.). However, these solutions result in far more expensive and more complicated devices without a significant improvement of the accuracy of thermophysical measurements.

\section{Aim of the research}

The research aims to review the thermometric bridge circuits created using the methodological approached that we proposed and thermophysical devices developed on their basis.

\section{Results and their discussion}

Over decades, the Department of Automation and Computer-Integrated Technologies (Lviv Polytechnic National University) has come up with new methodological approaches to the development of thermophysical devices allowing high-accuracy measurements across a wide range of thermal conductivity values. The proposed approaches rely on the principle of invariance, which ensures the compensation of the effect of various non-informative parameters on the measurement result [4]. The idea is that in a measuring device, in addition to the measuring circuit (channel), a comparative circuit (channel) is created that is not fed with an input signal, but which, similarly to the measuring channel, is under the effect of some external factors - perturbations, i.e. non-informative parameters. The parameters of the comparative channel are to be selected in such a way so that a change of its signal effected by perturbations is identical to the change of measuring channel signal under the effect of these same perturbations, i.e. perturbations enter the measuring device through both channels simultaneously. Using the difference in signals between the measuring channel and comparative channel provides for the independence (invariance) of the resulting signal from the perturbations, meaning that the method ensures the elimination of additional errors caused by the effect of these perturbations (non-informative parameters) on the measurement result.

The double-channel principle is especially efficiently implemented in bridge measuring circuits, based on which thermal conductivity measuring devices will be designed. This said, we can formulate the underlying principles of the design of thermometric bridge circuits (TBC):

- the measuring circuit comprises two parallel thermal circuits;

- identical temperature differentials are created at their ends;

- each thermal circuit includes thermal resistances with known values, and at least one of them comprises the thermal resistance the value of which is to be determined.

For calculating the developed TBC (balanced, unbalanced and partially balanced), the theory of thermal circuits was applied. Heat exchange problems in a system of objects are solved assuming that this system is a thermal circuit. Using the analogy between electricity transfer and heat transfer, the theory of electrical circuits is applied [5].

Each measuring device has a certain specific task and is designed in accordance with the specific measuring circuitry. Selection of a measuring device design relies on a number of factors, including the measurement range, required accuracy and maximum possible design simplicity.

The methods that we proposed spare the need to measure absolute values of heat fluxes. The sought-for value is evaluated based on the temperature differentials in different sections of the thermal circuit, which is why they were termed thermometric.

For determining the thermal conductivity coefficient for gas or liquid layers, the unbalanced bridge method was used [6]. In this method, two thermal circuits are created between the heat source and heat sink; one is made of the test specimen and reference specimen, the other of the reference specimen and test specimen. The temperature differential between the contact areas of the specimen is measured, and the thermal conductivity coefficient of the test specimen is calculated. The schematic diagram of the device implementing the unbalanced TBC is presented in Fig.1. 


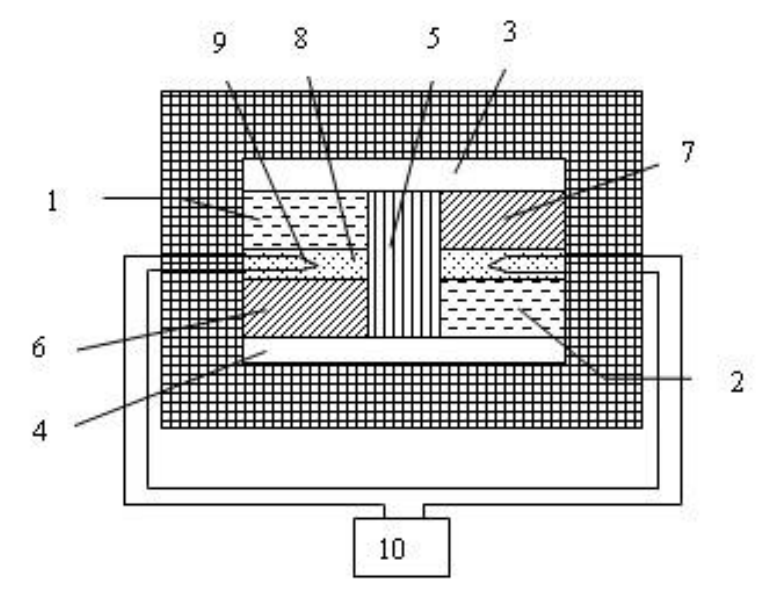

Fig.1. The schematic diagram of the device for measuring the thermal conductivity of materials based on the unbalanced thermometric bridge circuit: 1, 2- test medium; 3- heater; 4- cooler; 5- heat-insulating layer; 6, 7- reference specimen; 8- partition; 9- temperature sensors; 10 - secondary device.

As a basis for developing the device for measuring the thermal conductivity of construction and heatinsulating materials, a partially balanced TBC with in-series connection of the test and reference specimen was used [7]. The diagram of thermal resistances connection in such a design is presented in Fig.2.

It is proposed that the thermally conductive element should be implemented in the form of $\mathrm{N}$ parallel thermally conductive elements, each of them having one junction of a differential thermal couple mounted into it, which by turns switch to this thermal couple junction located between the test and reference specimen.

Each thermally conductive element provides a certain point of balance:

$$
\begin{aligned}
& \text { the first }\left(\frac{R_{x}}{R_{e}}\right)_{1}=\frac{R_{K 1}+R_{11}+R_{K 2}}{R_{K 1}+R_{21}+R_{K 2}}=a_{1}, \\
& \text { the second }\left(\frac{R_{x}}{R_{e}}\right)_{2}=\frac{R_{K 1}+R_{12}+R_{K 2}}{R_{K 1}+R_{22}+R_{K 2}}=a_{2}, \\
& \text { the (N-1)-th }\left(\frac{R_{x}}{R_{e}}\right)_{N-1}=\frac{R_{K 1}+R_{1(N-1)}+R_{K 2}}{R_{K 1}+R_{2(N-1)}+R_{K 2}}=a_{N-1}, \\
& \text { the } \mathrm{N}-\operatorname{th}\left(\frac{R_{x}}{R_{e}}\right)_{N}=\frac{R_{K 1}+R_{1 N}+R_{K 2}}{R_{K 1}+R_{2 N}+R_{K 2}}=a_{N} .
\end{aligned}
$$

By denoting the measurement range that is ensured by the measurement device as $\frac{R_{x \max }}{R_{x \min }}=\frac{a_{1}}{a_{N}}=D$, the ratio $\frac{a_{1}}{a_{2}}=\frac{a_{2}}{a_{3}}=\ldots=\frac{a_{N-1}}{a_{N}}=d$ can be written as:

$$
d^{N}=D,
$$

where $\mathrm{N}$ is the number of thermally conductive elements.

Therefrom, the required number of thermally conductive elements can be found:

$$
N=\lg D / \lg d .
$$




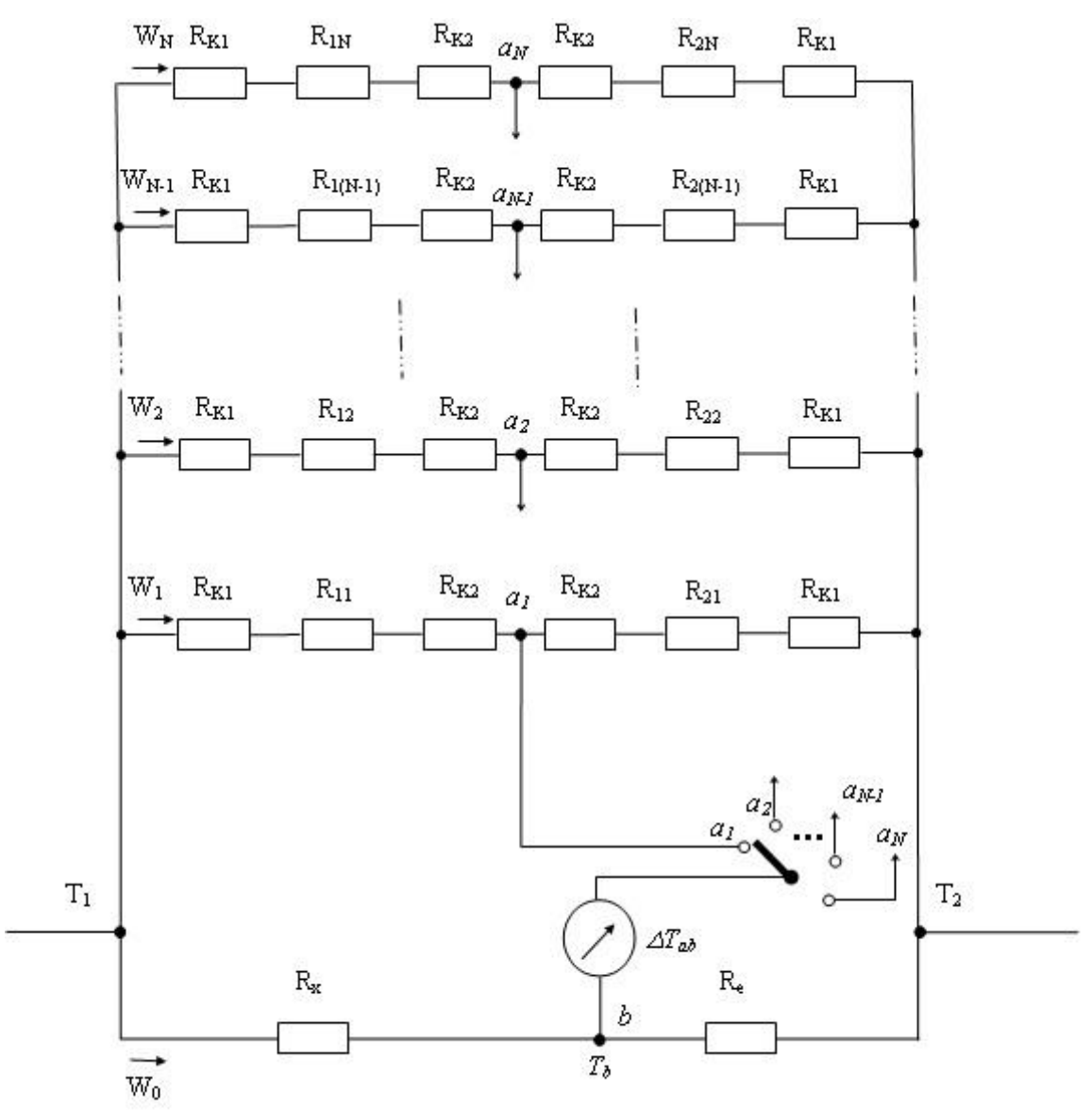

Fig.2. The diagram of thermal resistances connection and distribution of heat fluxes and temperatures in the developed TBC, where $\Delta T_{12}=T_{1}-T_{2}$ is the temperature differential between the heat source and heat sink; $\Delta T_{a b}=T_{a}-T_{b}$ is the temperature differential in the measuring diagonal; $\mathrm{R}_{\mathrm{x}}, \mathrm{R}_{\mathrm{e}}$, are thermal resistances of the test and reference specimen, respectively; $\mathrm{R}_{\mathrm{K} 1}, \mathrm{R}_{\mathrm{K} 2}$ are contact

thermal resistances at the ends of the thermally conductive elements and at the point of the temperature sensors mounting, respectively; $R_{11}, R_{12}, \ldots, R_{1 N}$ are thermal resistances of the parts of the thermally conductive materials adjacent to the heat source;

$R_{21}, R_{22}, \ldots, R_{2 N}$ are thermal resistances of the parts of the thermally conductive materials adjacent to the heat sink, $\mathrm{W}_{0}, \mathrm{~W}_{1}, \mathrm{~W}_{2}, \ldots, \mathrm{W}_{\mathrm{N}}$ are heat fluxes in different branches of the bridge circuit.

Based on this TBC, the device for measuring the thermal conductivity of construction and heat-insulating materials across the range $0.03-1 \mathrm{~W} /(\mathrm{m} \cdot \mathrm{K})$ was developed.

The schematic diagram of the developed device is shown in Fig.3.

The heat fluxes in the thermal circuits are defined by the heat source 1 . Between the heat source 1 and heat sink 2 there are the test specimen 3 and reference specimen 4 divided by a temperature-equalizing plate 5 , with a junction of the differential thermal couple 6 mounted into it. The lateral surfaces of the specimen are protected from heat exchange with the environment by protective plates 7. Between the heat source 12 and heat sink 11, there are thermally conductive elements. The lateral surface of the thermally conductive elements is protected from heat exchange with the environment by the heat-insulating casing 13. Into the thermally conductive elements, the second junction of the differential thermal couple 9 is mounted. The parts of the thermally conductive cell are fixed by the cabinet 14. The temperatures of the heat source 1 and 12, and heat sinks 2 and 11 are set and maintained using the liquid thermostats 15 and 16, respectively. Equality to zero of the signal of the differential thermal couple 6 is controlled using the null indicator 17.

The heat sources and heat sinks are made as flow chambers with the circulating heat carriers at the temperatures set by the corresponding thermostats. 

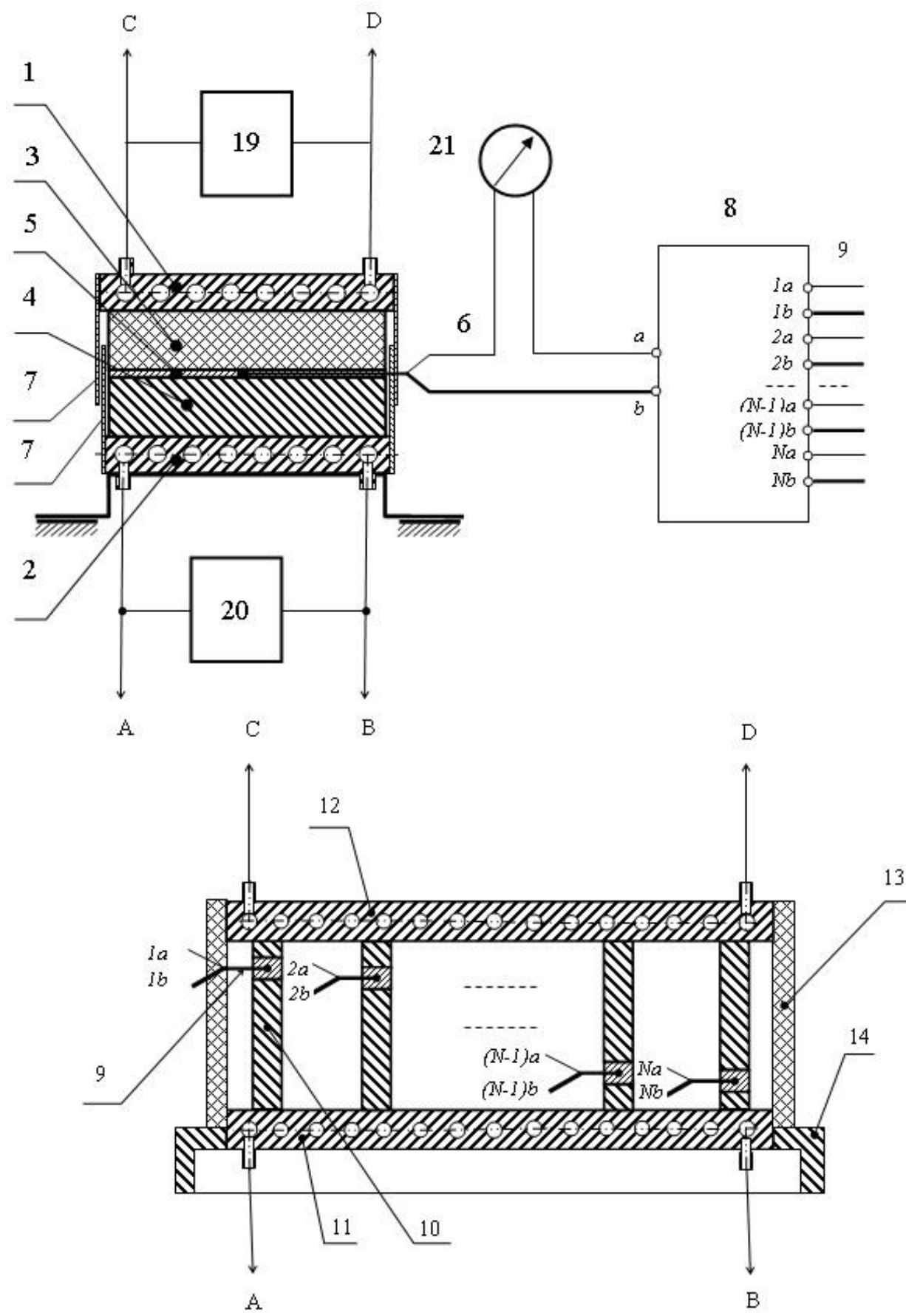

Fig.3. The schematic diagram of the device for measuring the thermal conductivity of construction and heat-insulating materials across the range $0.03-1 \mathrm{~W} /(\mathrm{m} \cdot \mathrm{K}): 1$ - heat source; 2 - heat sink; 3 - test specimen; 4 - reference specimen; 5 - temperatureequalizing plate; 6 - differential thermal couple; 7 - protective plates; 8 - switch of the differential thermal couple junctions; 9 - differential thermal couple junctions; 10 - thermal resistances of the thermally conductive element; 11 - heat sink; 12 - heat source; 13 - heat-insulating casing; 14 - cabinet; 15,16 - thermostats; 17 - null indicator.

The measurements are made according to the following procedure. The thermostats 15 and 16 are switched on to ensure the heat carriers circulation in the respective chambers. The test specimen 3 is mounted on the temperatureequalizing plate 5 and pressed down by the heat source 1 .

Using the switch of the differential thermal couple junctions 8 and switches of the thermal couples of the thermally conductive elements 9 , the junctions of the differential thermal couple 6 are by turns switched to the null indicator 17. This is done until the minimum temperature differential between the test specimen 3/reference specimen 4 contact area and the point at the axis of a thermally conductive element is determined. Thereat, using the 
measured temperature differential and thermally conductive element number, and calibration characteristics, the thermal conductivity coefficient is calculated.

Besides, we also developed a number of balanced TBC and devices on their basis, correspondingly.

For measuring the thermal conductivity of high thermal conductive plates and sheet materials in the range up to $400 \mathrm{~W}(/ \mathrm{m} \cdot \mathrm{K})$ and higher, the balanced thermometric bridge circuit was proposed and based on it, the device was constructed [8] with balanced heat fluxes flowing through the reference specimen.

The thermometric bridge circuit based on which such a device is built is shown in Fig.4.

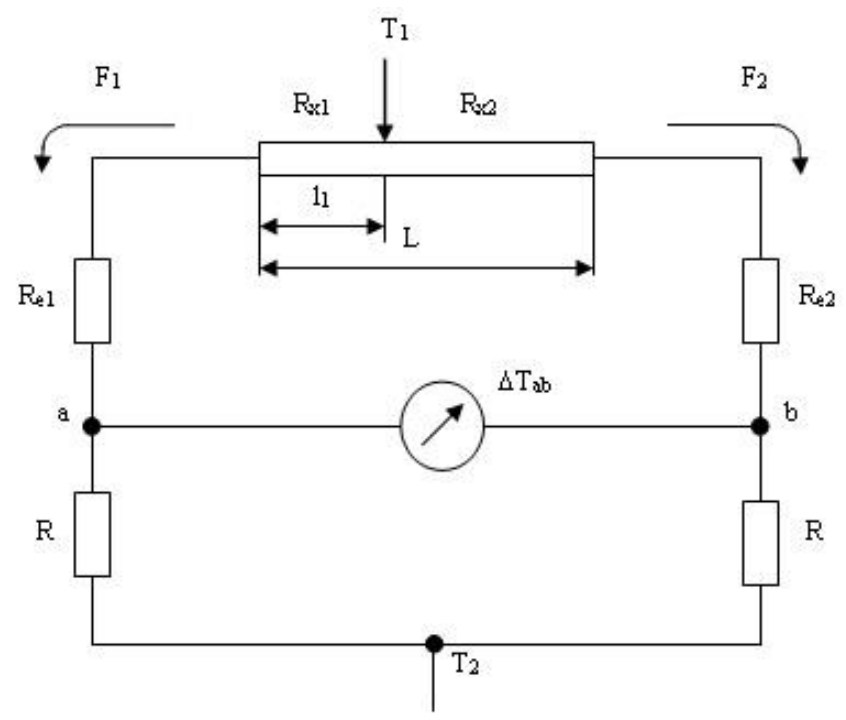

Fig.4. The diagram of thermal resistances connection and distribution of heat fluxes and temperatures in the balanced thermometric bridge circuit with balanced heat fluxes flowing through the reference specimen.

For this circuit, the following system of equations can be written:

$$
\left\{\begin{array}{l}
F_{1}=\frac{T_{1}-T_{a}}{R_{x 1}+R_{e 1}}=\frac{T_{a}-T_{2}}{R} ; \\
F_{2}=\frac{T_{1}-T_{b}}{R_{x 2}+R_{e 2}}=\frac{T_{b}-T_{2}}{R} ;
\end{array}\right.
$$

where $T_{l}$ is the temperature of the heat source; $T_{2}$ is the temperature of the heat sink; $T_{a}, T_{b}$ are the temperatures in the measuring diagonal; $R_{x 1}, R_{x 2}$ are thermal resistances of the test specimen parts; $R_{e l}, R_{e 2}$ are thermal resistances of the first and second reference specimen, respectively; $R$ is the thermal resistance of the thermometric elements.

The condition of the equality of the heat fluxes $\left(F_{1}=F_{2}\right)$ flowing through the reference specimen is achieved by the influence of the heat flux on the limited zone of the test specimen and transfer of the location (delivery) of this flux influence onto the test specimen. Taking into consideration that the thermometric elements are identical and satisfying the condition of the equality of the heat fluxes flowing through the different thermally conductive circuits, we obtain $\Delta T_{a b}=T_{a}-T_{b}=0$. From the system of equations (4), considering the above conditions $F_{1}=F_{2}$ and $\Delta T_{a b}=0$, the equation of balance is written as:

$$
R_{x 1}+R_{e 1}=R_{x 2}+R_{e 2}
$$

Therefrom, by expressing the values of the thermal resistances of the thermometric circuit elements through their geometric dimensions and thermal conductivity, we obtain the formula for calculating the thermal conductivity coefficient for the test specimen: 


$$
\lambda_{x}=\frac{L-2 l_{1}}{S_{x}\left(\frac{l_{e 1}}{\lambda_{e 1} \cdot S_{e 1}}-\frac{l_{e 2}}{\lambda_{e 2} \cdot S_{e 2}}\right)},
$$

where $\lambda_{x}, \lambda_{e l}, \lambda_{e 2}$ are the thermal conductivity coefficients of the test specimen and the first and second reference specimen, respectively; $L$ is the distance between the reference specimen; $l_{l}$ is the distance from the middle of the location of the heat influence to one of the reference specimen; $l_{e l}, l_{e 2}$ are the thicknesses of the first and second reference specimen, respectively; $S_{x}, S_{e l}, S_{e 2}$ are the cross sectional areas of the test specimen and the first and second reference specimen, respectively.

As a result of the simple transformations, we obtain

$$
\lambda_{x}=A-B \cdot l_{1},
$$

where $A$ and $B$ are the constants of the device, which are determined by calibration, and

$$
A=\frac{L}{S_{x}\left(\frac{l_{e 1}}{\lambda_{e 1} \cdot S_{e 1}}-\frac{l_{e 2}}{\lambda_{e 2} \cdot S_{e 2}}\right)}, B=\frac{2}{S_{x}\left(\frac{l_{e 1}}{\lambda_{e 1} \cdot S_{e 1}}-\frac{l_{e 2}}{\lambda_{e 2} \cdot S_{e 2}}\right)} .
$$

The schematic diagram of the device for measuring the thermal conductivity of high thermal conductive sheet materials is shown in Fig.5.

The heat source 1 forms a narrow stream of infrared rays targeting the surface of the test plate 3 , which contacts the surfaces of the two specimen packages. The specimen packages are fixed on the surface of the heat sink 2 . They consist of the thermometric elements 4 , temperature-equalizing plates 5, reference specimen 6 and 7 with different thermal resistances and contact elements 8 made of high thermal conductive rubber. The test plate 3 is pressed against the packages by spring fixture 9 fixed on the cabinet 10 by moving the heat sink 2 along the guides 11 with the nut 12 and screw 13, which is rotated by the handle 14 .

In the temperature-equalizing plates 5 there are junctions of the differential thermal couple 15 connected to the amplifier 16, the signal $\Delta T_{a b}$ from which is fed onto the control unit 17, which regulated the operation of the motor M. The motor drives the screw 18, which changes the position of the nut 19 along the guide 20 and thereby the position of the heat source $1 l_{l}$ until the signal of the differential thermal couple $\Delta T_{a b}$ reaches zero. Then the measurement result is displayed on the indicator 21. The temperature of the heat sink 2 is set using the thermostat 22 .

The method was proposed and on its basis, the device was built for measuring the thermal conductivity of high thermal conductive materials for cylinder-shaped test specimen in the range up to $400 \mathrm{~W} / \mathrm{m} \cdot \mathrm{K}$ and higher [9].

The thermometric bridge circuit that is the basis for the design of this device is shown in Fig.6.

For the balance of the thermometric circuit $\left(\Delta T_{a b}=0\right)$ :

$$
R_{x}+R_{l}=R_{e}+R_{2} .
$$

Therefrom, we obtain the formula for calculating the thermal conductivity coefficient of the test specimen:

$$
\lambda_{x}=\frac{l_{x}}{S_{x}\left(\frac{l_{e}}{\lambda_{e} S_{e}}-\frac{l_{1}-l_{2}}{\lambda_{T} S_{T}}\right)}=\frac{l_{x}}{S_{x}\left(\frac{l_{e}}{\lambda_{e} S_{e}}-\frac{2 \cdot \Delta l}{\lambda_{T} S_{T}}\right)},
$$

where $\lambda_{\mathrm{x}}, \lambda_{\mathrm{e}}, \lambda_{\mathrm{T}}$ are the thermal conductivity coefficients of the test specimen, reference specimen and thermally conductive element, respectively; $l_{\mathrm{x}}, l_{\mathrm{e}}$ are the thicknesses of the test and reference specimen, respectively; $l_{1}$ is the distance from the location of the heat flux influence to the test specimen; $l_{2}$ is the distance from the location of the 
heat flux influence to the reference specimen; $S_{x}, S_{e}, S_{T}$ are the cross-sectional areas of the test specimen, reference specimen and thermally conductive element, respectively.

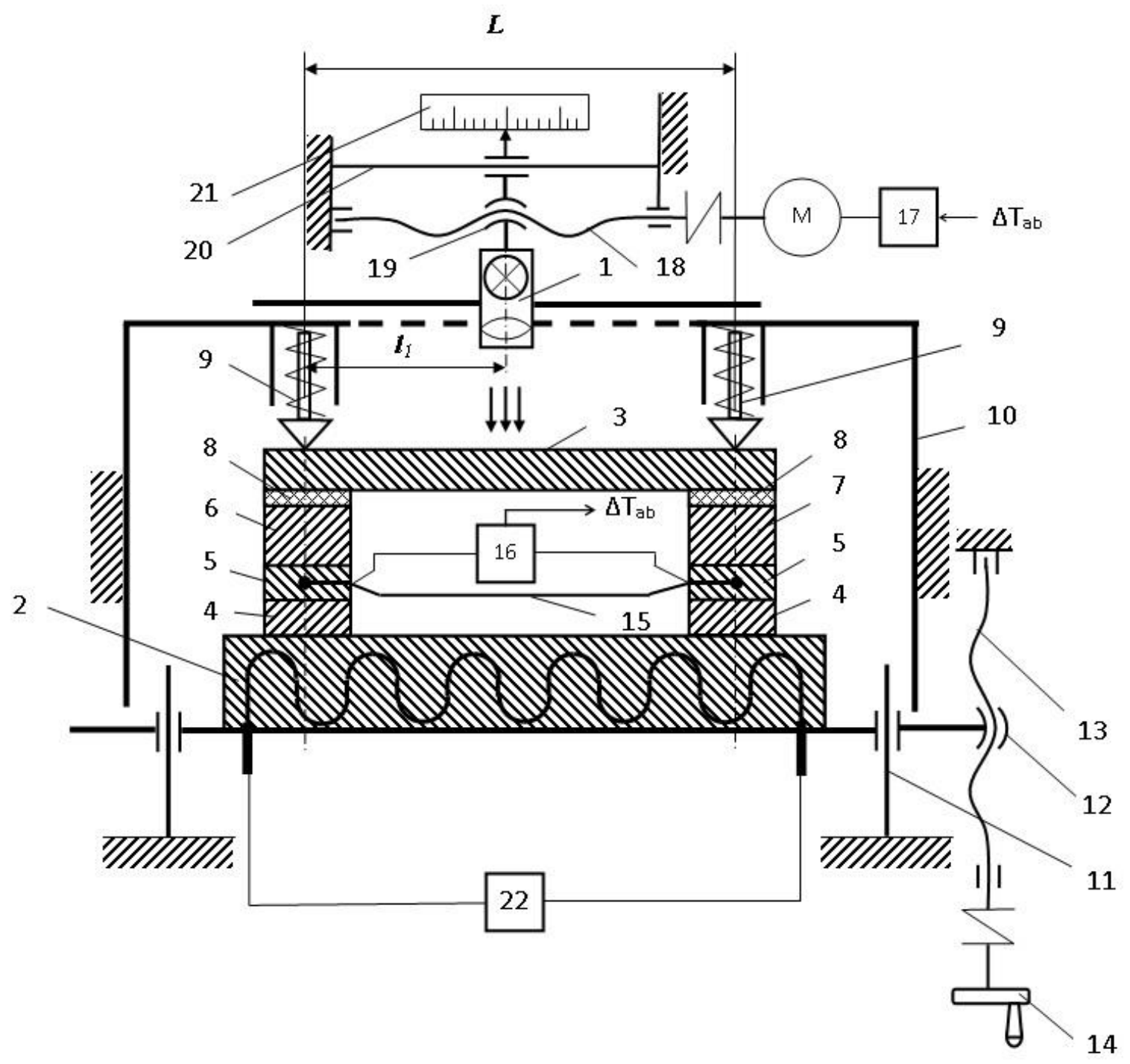

Fig.5. The schematic diagram for measuring the thermal conductivity of sheet materials: 1 - heat source; 2 - heat sink; 3 - test plate; 4 - thermometric elements; 5 - temperature-equalizing plates; 6,7 - reference specimen; 8 - contact elements; 9 - fixtures; 10 - cabinet; 11 - guides; 12 - nut; 13 - screw; 14 - handle; 15 - differential thermal couple; 16 - amplifier; 17 - control unit; 18 - screw; 19 - nut; 20 - guide; 21 - indicator; 22 - thermostat.

The schematic diagram of this device is presented in Fig.7.

The heat fluxes in the thermally conductive circuits of the device are set by the electric heater 1 located on the thermally conductive element 3 with an option of its moving along its axis. The faces of the thermally conductive element 3 adjoin the test specimen 7 and reference specimen 8 , which are pressed against them by the heat sinks, rods 19, springs 20 and plates 21 . The heat sinks are made as copper units 9 , which are flown over by the liquid from the thermostat 12 circulating in the chambers 10. On top of the copper units there are glued the thermometric elements 26 with identical thermal resistances and copper temperature-equalizing plates 4 with the junctions of the differential thermal couple 5 connected to the null indicator 6.

The electric heater 1 on the thermally conductive element 3 is covered by the cabinet 13 . It is moved by the handle 17 , which drives the slide 14 with the help of the stoppers 15. 


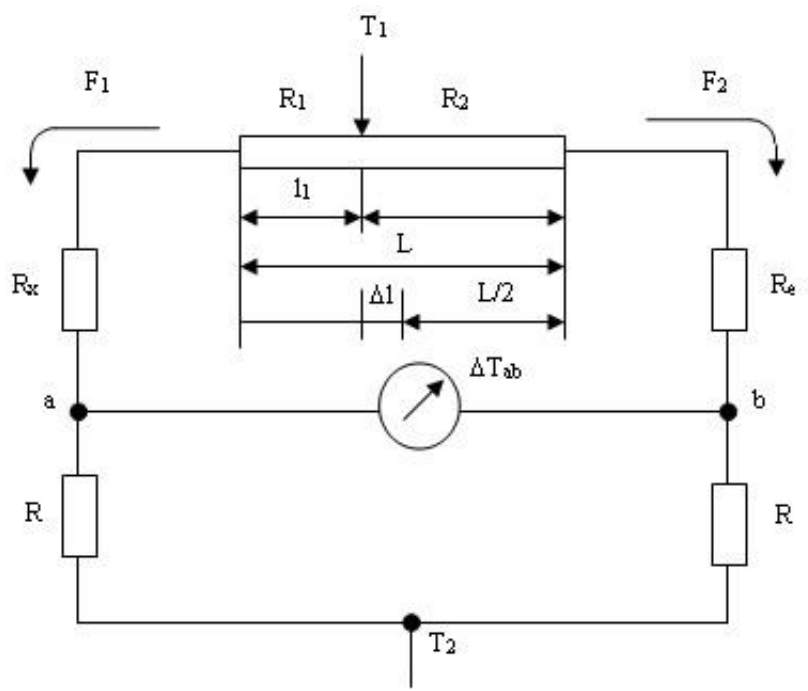

Fig.6. The diagram of thermal resistances connection and distribution of heat fluxes and temperatures in the balanced thermometric bridge circuit with balanced heat fluxes flowing through the test and reference specimen.

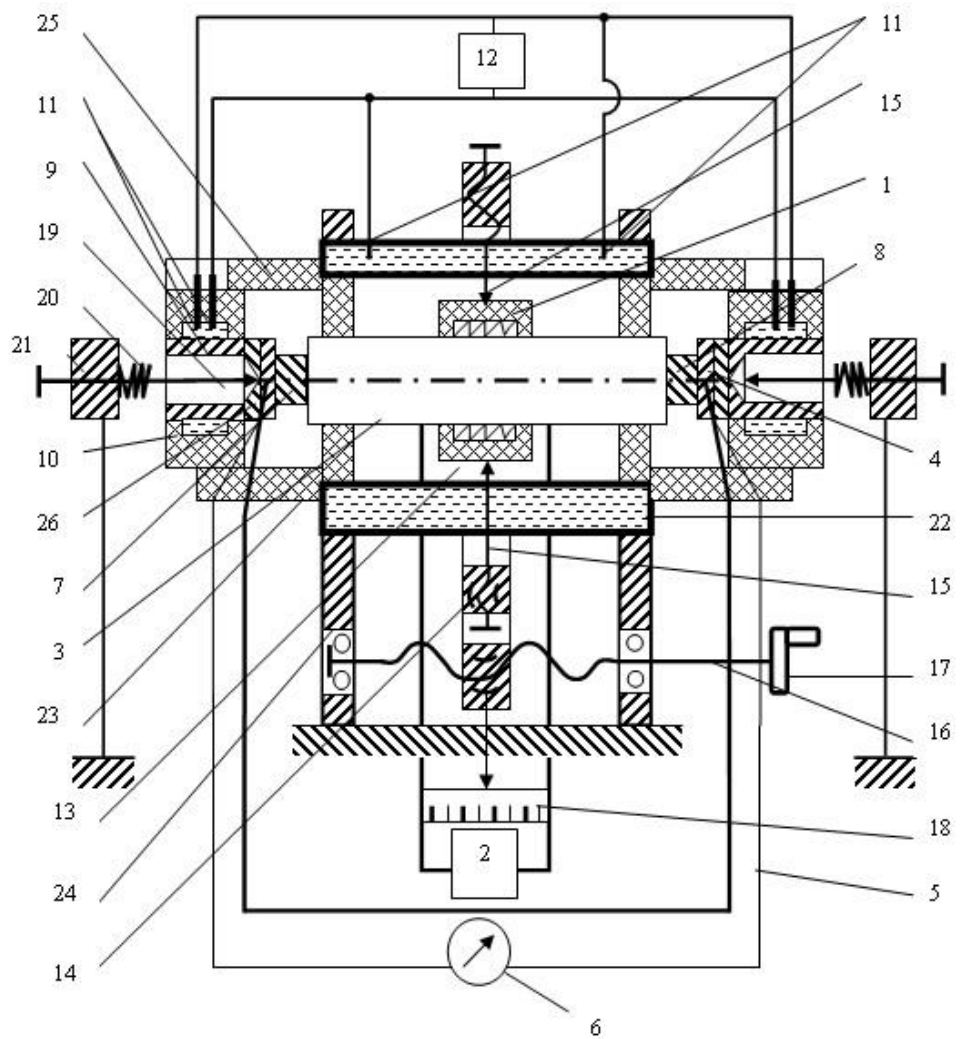

Fig.7. The schematic diagram for measuring the thermal conductivity of high thermal conductive materials for prism-shaped test specimen: 1 - electric heater; 2 - power supply; 3 - thermally conductive element; 4 - temperature-equalizing plates; 5 - differential thermal couple; 6 - null indicator; 7 - test specimen; 8 - reference specimen; 9 - copper units; 10 - chambers; 11 - joining pipes; 12 - liquid thermostat; 13 - heater cabinet; 14 - slide; 15 - stoppers; 16 - screw; 17 - handle; 18 - indicator; 19 - rods; 20 - springs; 21 - plates; 22 - casing; 23 - heat-insulating inserts; 24 - bearing supports; 25 - heat-insulating shields; 26 - thermometric elements.

The casing 22 ensures maintaining the temperature of the medium surrounding the thermally conductive element 3 at the level of the temperature of the heat sinks. It is made as a chamber of copper in which the heat carrier from the thermostat circulates. The thermally conductive element 3 is aligned with respect to the casing 22 by the heat- 
insulating inserts 23. In its turn, the casing 22 is fixed in the bearing supports 24 . While making measurements, in order to reduce heat loss through the lateral surfaces of the test specimen 7 and reference specimen 8 , they are covered by the heat-insulating shields 25 , mobile with respect to the chambers 10 . A deviation $\Delta l$ of the heat source with respect to the middle of the thermally conductive element is displayed on the indicator 18 .

\title{
5. Conclusion
}

Designing the devices based on thermometric bridge circuits makes it possible to improve significantly the accuracy of measuring thermophysical characteristics of materials by reducing the errors of measuring the absolute values of the temperature and their differentials, heat fluxes flowing through the specimen, influence of the heat source and heat sink temperatures and other non-informative parameters on the measurement result. This in turn enables measurements across a wide range of thermal conductivity values, and, due to the simplified measurement circuitry, ensures a significantly better reliability and lower cost of the devices in which these circuits are implemented.

\section{References}

[1] Herashchenko, O.A., Hryshchenko, T.H. Devices for Thermophysical Measurements. Catalogue. K., 1991. (in Russian)

[2] Thermophysical Measurements and Devices. Edited by E.S. Platunov. - L.: Mashynostroenie Journal, Leningrad Division, 1986. - 256 p. (in Russian)

[3] Sergeev, O.A. Metrological Fundamentals of Thermophysical Measurements. - M.: Standards Publishers, 1972. - 154 p. (in Russian)

[4] Petrov, B.N., Viktorov, V.A. et al. The Principle of Invariance in Measuring Devices. - M.: Nauka Publishers, 1976. - 244 p. (in Russian)

[5] Dulniev, G.N. Heat and Mass Exchange in Radioelectronic Devices. - M.: Vysshaya Shkola Publishers, 1984. - 247 p. (in Russian)

[6] Inventor's Certificate 428260 (USSR). A Method of Measuring Thermophysical Characteristics of Gas and Liquid Layers. Pistun, E.P., Rogotskiy Ya.T. - Published in Inventions Bulletin, No18, 1974. (in Russian)

[7] Vasylkivskyi, I. A Thermal Conductivity Measuring Converter for Construction Materials Based on a New Partially Balanced Thermometric Bridge Circuit / I. Vasylkivskyi, Ya. Yusyk // Lviv Polytechnic National University Bulletin. - 2013. - No758: Heat Power Engineering. Environmental Engineering. Automation. - pp. 164-169. (in Ukrainian)

[8] Inventor's Certificate 1681216 (USSR). A Method of Measuring the Thermal Conductivity of Materials. Pistun, E.P., Rogotskiy Ya.T., Vasylkivskyi, I.S., Yusyk, Ya.P. - Published in Inventions Bulletin, No36. 1991. (in Russian)

[9] Inventor's Certificate 1536969 (USSR). A Method of Measuring the Thermal Conductivity of Substances. Pistun, E.P., Rogotskiy Ya.T., Vasylkivskyi, I.S., Yusyk, Ya.P. (Restricted circulation). (in Russian)

\section{Температурометричні мостові схеми для вимірювання теплофізичних характеристик}

\author{
Ігор Васильківський, Василь Фединець, Ярослав Юсик
}

Національний університет «Львівська політехніка», вул. Степана Бандери, 12, Львів, 79013, Україна

\section{Анотація}

В даній статті приведено конструкції ряду приладів для вимірювання теплопровідності твердих матеріалів розроблені на основі нових методологічних підходів, запропонованих авторами статті, що дозволяють проводити вимірювання в широкому діапазоні значень теплопровідності з вищою точністю. В основі запропонованих підходів було використано принцип інваріантності - забезпечення компенсації впливу різних неінформативних параметрів на результат вимірювання. Для розрахунку розроблених мостових теплових вимірювальних схем (зрівноважених, незрівноважених та неповного зрівноваження) застосовано теорію теплових кіл, яка грунтується на аналогії процесів переносу тепла й електрики. Побудова приладів для вимірювання теплопровідності на основі мостових теплових вимірювальних схем дає змогу значно підвищити точність вимірювання теплофізичних характеристик матеріалів за рахунок зменшення похибок від впливу неінформативних параметрів на результат вимірювань. Це в свою чергу дало змогу розширити діапазон вимірювання значень теплопровідності, підвищити надійність і зменшити собівартість приладів внаслідок спрощення вимірювальної схеми.

Ключові слова: коефіцієнт теплопровідності; мостова теплова вимірювальна схема; досліджуваний зразок; еталонний зразок; тепловий опір; теплопровідне коло. 